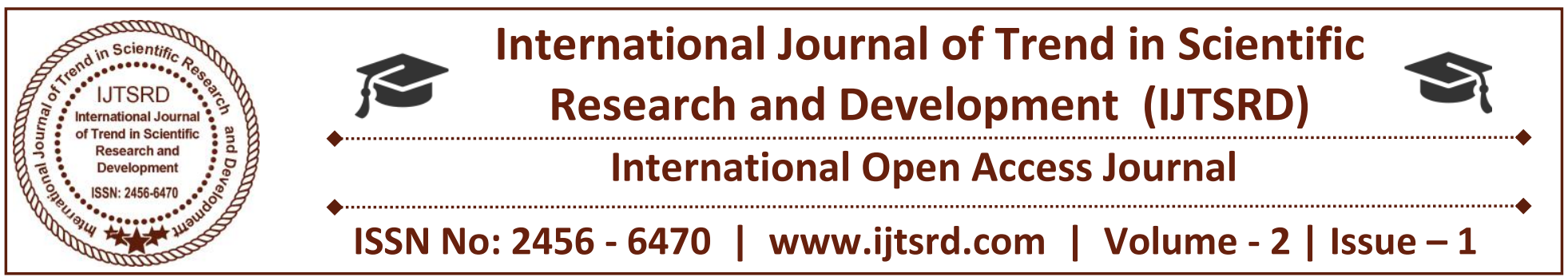

\title{
Education for Sustainable Development
}

\author{
Santosh Kumar Chattaraj \\ Headmaster, Nutandanga High School. \\ Pandaveswar, West Bengal, India
}

\begin{abstract}
Development that meet the needs of the present without comprising the ability of future generation to meet their own needs. South Asian Association of Regional Corporation faces now an important number of interlinked priorities in the early $21^{\text {st }}$ century, including the economical \& social consequence of the global financial crisis, climate change, declining water \& energy resources, shrinking biodiversity, threats to food security \& health risks. ESD is a lifelong learning perspective is essential for the achievement of a sustainable society $\&$ is therefore desirable at all levels of formal education \& training, as like formal $\&$ non formal education. Education \& training are in dispensable to achieving a more sustainable South Asia \& world should be regarded as crucial in the process of lifelong learning and should, where appropriate, be main streamed into all levels and aspects of education \& Training, in order to strengthen the capacity of citizens to cope with imminent unpredictable problems \& to find long-term solutions for there in many different situations throughout life.
\end{abstract}

\section{Keywords: Development, Training, Education, Shrinking}

\section{INTRODUCTION}

In current years, three main areas have been identified that affect the requests regretted by educationists. There is an important trends is the emphasis on educations training is seen by many as the most important factor influencing economic growth in accordance with the 2006 world bank study. The concept of knowledge society was made to indicate not only widen participation in wider education or knowledge based sectors of the economy, but rather a situation in which the characteristics of work organic section is changing under the important \& growing influence of knowledge. Another direction shows the changes in the labor market structure. in 2000, it was introduced the concept of "Labor market transition " to indicate how in modern society, the demarcation lines between work, leisure, education \& care, have been blurred to such loss that lead to increased patterns of mobility \& flexibility in order to destandardization of learning \& overall emphasis placed on employment opportunities. It is an important proof of the fact that the transition is non-linear \& chaotic, being influenced by the fact that many early school graduates are affected by being in a precarious financial situation.

Integrating key sustainable development issues in to teaching \& learning. It may include, for example, instruction about climate change, disaster risk reduction, bio diversity and poverty reduction and sustainable consumption. It also requires participatory teaching \& learning methods that motivate and empower learners to change their behaviors and take action for sustainable development. ESD consequently promotes competencies like critical thinking imagining future scenarios and making decisions in a collaborative way.

The aspiration of sustainable development requires us to resolve common problems and tensions and to recognize new horizons. Economic growth \& the creation of wealth have reduced global poverty rates, but vulnerability, inequality, exclusion and violence have in-world. Unsustainable patterns at economic growth \& the creation at wealth have reduced global 
poverty rates, but vulnerability, inequality, exclusion and violence have increased within and across societies throughout the world. Unsustainable patterns at economic production and consumption contribute to global warming environmental degradation and upsurge in natural disasters. Moreover, while environmental human list frame works have been strengthened over the past several decades, the implementation and protection at these norms remain a challenge. For example despite the progressive empowerment at woman through greater access to education, they continue to face discrimination in public life and in employment, violence against women and children particularly girls, continues to undermine their rights. Again, while technological development contributes to greater interconnectedness and offers new avenues for exchange, cooperation and solidarity. We also see an increase in cultural and religious intolerance identity based political mobilization conflict.

Education must find ways at responding to such challenges, facing into account multiple world views and alternative knowledge systems, as well as new frontiers in science \& technology such as the advances in neurosciences and the development in digital technology. Rethinking the purpose of education and the organization of learning has never been more urgent.

From a political point of view we can say that the idea of sustainability comes from two different trends developed after the $2^{\text {nd }}$ world war, which can be related to when colony power ended their occupation. Within the first trend, it was noticed that the former colonies suffered from social \& economical problems like poverty and lack of food. The nation therefore arranged several conferences where solution to these problems was outlined. Several international organs were established, including the IMF \& The World Bank Group. The $2^{\text {nd }}$ trend starts out from the alarming reports that began to appear during the 1960s, which warned for humans' way of using nature resources. The resources would come to an end because of the future economical growth $\&$ increase in population. A $1^{\text {st }}$ attempt discussed there trend could be seen during the UN conference on the environmental in Stockholm 1972.

The $1^{\text {st }}$ conference concerning environmental education was held in Teblisi in 1977 \& it resulted in the Teblesi declaration. The document focuses on EF
\& it maintains among others that it should be interdisciplinary, be a lifelong process \& develop critical thinking \& problem-Solving skills. The declaration has had a large effect on curriculums. For example in the Uganda strategy to implementing education for sustainable development. The term Sustainable Development got an international breakthrough in1987 with the Brunt land Commissions final report, our common future. The principles underlying sustainable can economic growth is used to be seen as a requirement for development. No country can active a sustainable economic growth if the environment is worsened, if the prosperity is not fairly distributed \& the growth of the human resources has not taken place. Therefore, the economical dimension means that economical growth shall carry on with $1^{\text {st }}$ respect taken to the environment, $2^{\text {nd }}$ growth of the people's health \& education $\& 3^{\text {rd }}$ a fair distribution of prosperity. The social dimension points out the importance resources, power, \& influence fairly distributed \& that people can feel security \& can participate. The social dimension is therefore a requirement for economic growth. The environmental dimension means that considerations are taken for the social \& economical development. These dimensions are integrated with each other as they are interdependent \& mutually reinforcing.

\section{LIFELONG LEARNING BASE FOR SUSTAINABLE DEVELOPMENT}

UNESCO invited Government \& non Governmental Organization with official partnerships with UNESCO to nominate $\&$ individuals, institutions working in the field of education for sustainable development in order to be part of the UNESCO award. It is necessary that the basis of qualifications at all citizens to be constantly renewed at any stage of life to cope with the challenges \& present and future technological development. While quality education at primary, secondary \& tertiary education is crucial ongoing trainings and educations outside the class rooms are becoming more important. In a rapidly changing global economy, knowledge becomes the most valuable asset of the world. This created an increased need for (re) education training in all stages of life.

The UN decade of education for sustainable development took place from 2005 to 2014, with the goal of emphasizing education in all its form as an indispensable element for achieving sustainable development in November 2014, as the officials 
follow up to the DESD, UNESCO launched the Global Action Programmed for ESD with the overall objective to scale up action on ESD word wide. Two basic and very important objectives of GAP ON ESD are,

1. Reorienting education \& learning so that everyone has the opportunity to secure the values, skills \& knowledge that empower them to contribute to sustainable development.

2. Enhancing the role of education \& learning in all relevant agendas, programmes and activities that promote sustainable development. The GAP focussing on generating and sealing up action in five priority action areas: 1. Advancing policy, 2. Transforming learning and training environment, 3. Building capacities of educators \& trainers, 4. Empowering \& mobilizing youth 5. Accelerating sustainable solution sat local level. Due to its long linkages with sustainable development, the GAP on ESD provides an excellent frame work for understanding the types of education, training and public awareness initiatives conducive to enabling people of all ages to understand and implement solutions for solving the complex problems presented by climate change.

By 2030, ensure that all learners' acquire knowledge \& skills needed to promote sustainable development, including among others, in August 2015, 193 countries agreed on the following goals-

No to poverty, End poverty in all its forms everywhere. Not for hunger. Ending hunger, achieving food security, improving nutrition and promoting sustainable agriculture, good health, ensure healthy living and promote well being for all ages. Quality education ensures universal and equal quality education \& enhances lifelong learning opportunities for all. Gender equality achieves gender quality \& empowers all women \& girls. Clean and healthy water. Ensure abundance and sustainable water and health management for all. Renew Sustainable access $\&$ atonable energy. Ensure affordable, reliable and sustainable energy access for all. Good jobs \& economy economics. Promote sustainable, comprehensive and sustainable economic growth, full $\&$ productive employment and decent for all. Innovative and good infrastructure. Build flexible infrastructure and prate comprehensive sustainable manufacturing \& innovation promotion. Promotion inequality within states \& between states \& each other. Cities and sustainable communities. Make cities \& human settlement inclusive secure flexible \& sustainable responsible use of resources. Ensure sustainable consumption \& production patterns. Climate move. Action to compete climate change and its impact. Sustainable access \& use of oceans, seas and marine resources for sustainable development. Sustain use of land. Protect, restore $\&$ promote the sustainable use of terrestrial ecosystems, sustainable manage forests combat desertification, halt \& restore land degradation and halt loss of biodiversity, peace $\&$ justice, promoting peaceful \& inclusive societies for sustainable development, providing access to justice for all and building effective, accountable \& inclusive institutions for all levels. Partnership sustainable development. Strengthening the means to implement revitalize the global partnership for sustainable development.

At the sometime, it is important to emphasize ESD's crucial importance for all the other 16 SDGs. With its overall aim to develop cross-cutting sustainability competencies in learners. ESD is an essential contribution to all efforts to achieve the SDGs enabling individuals to contribute to sustainable development by promoting social economic and political change as well as by transforming their own behaviour. ESD can produce specific cognitive, socio economical \& behavioural learning out comes that enable individuals to deal with the particular challenges at each SDG, thus facilitating its achievement. In short ESD enables all individuals to contribute to achieving the SDGs by equipping them with the knowledge \& competencies they need, not only to understand what the SDGs are about, but to change as informed citizens in bringing about the necessary transformation.

\section{CONCLUTION}

In line to the world political agenda which sets ambitious targets and expectations for education and training, that are oriented as well on the demographic change and on the need to create more "green jobs" we want to make several recommendations for the future implementation of this programmes: 1 . The new programme should move towards a system-based approach to mobility across all sect oral programmes; 2. The new programme should emphasize "learning mobility" as an essential element of lifelong learning and an important means of enhancing people's employability. It should also promote the recognition of outcomes of the mobility actions. Learning mobility can be seen as a means to enhance people's, 
knowledge, skills and competences and contributes to their personal development. It develops their social and civic competencies, sense of initiative, cultural awareness and expression and as a result enhances their employability and adaptability Proceedings of the 3rd International Conference The Economies of Balkan and Eastern Europe Countries in the changed world 257 3. The international dimension of the new programmes should be strengthened by: a) widening motilities and partnerships to include countries outside the EU, while the main focus should still remain on Europe b) making better links with other EU mobility programmes so we share outcomes and good practice c) exploring the use of Virtual Mobility to involve other countries outside the EU 4. The acquisition/development of language competence should be a more important element in the next programme for all motilities. 5. The future programme should support mobility of educational leaders and decision makers. They are a distinct group with an important multiplier role and have different needs to teachers, trainers and staff of education and training institutions. The domain that we proposed to analyze in this paper it was large and very interesting, because of the complexity implied by the implementation of changes in European higher education under the Bologna process and the economic environment because of his dynamics. Bologna reforms provide some tools to change that, if implemented properly. European Union level unit will produce positive effects including the protection of the rights and interests of students. Results from analysis once again highlighted the importance of mobility for placements both in the European educational and economic environment as well as the need to intensify cooperation in view to approach and even reach the targets set for sustainable development at EU level by 2020.

\section{REFERENCES}

1) Amfiteatru Economic. Quality assurance systems in higher education. Bucuresti, Sp. Iss. 2, pp. 612.

2) CEDEFOP (2009) : Future skill supply in Europe: Forecast up to 2020, Publications office, Luxembourg.

3) Decision No 1720/2006/EC of the EU Parliament and of the Council on 15th November Establishing an action programme in the field of lifelong

4) Ghergut, A. (2007); A battle between national mindsets and forces of business transition? John Wiley \& Sons, Inc, London, United Kingdom.

5) Severin I, et al. (2008); UNISO, Mobility: Asset for Professional Development, Iasi, pp. 163-167.

6) Sparrow,P.R. et al. (1997); Redefining the field of European Human Resource Management: 